\title{
Ganti Rezim Ganti Sistem
}

Shohibul Anshor Siregar

| Saya malah memastikan penyimpangan dan kerusakan Indonesia itu terjadi setiap era kepemimpinan|Karena itu andil setiap pemimpin puncak Indonesia tidak sepi dalam peta kerusakan atau penyimpangan Indonesia itu|

Tahun lalu saya bertemu Ratna Sarumpaet dan Sri-Bintang Pamungkas (SBP), dalam kesempatan yang berbeda, di Medan. Koordinator Masyarakat Pribumi Indonesia (MPI) Anwar Bakti Nasrallah, yang memiliki kontak intensif dengan kedua tokoh itu, yang meminta saya ikut dalam pertemuan yang dia rancang bersama kedua tokoh ini.

Dari kedua pertemuan itu saya menyimpulkan kesamaan kedua tokoh ini dalam menyuarakan koreksi dan perubahan demi kepentingan nasional. Mereka orang-orang yang selalu gelisah karena nasib bangsa. Berbeda latar belakang dan pengalaman, dan juga komunitas, pendekatan mereka pun tak menjadi soal bagi saya jika memiliki kekhasan masing-masing. Tetapi dalam satu hal mereka sama: "Kembali ke UUD 1945”. Itu solusi terbaik Indonesia yang juga disuarakan banyak tokoh termasuk Ketua Umum Majelis Pimpinan Nasional Pemuda Pancasila Kanjeng Pangeran Haryo Japto Soerjosoemarno, Sarwan Hamid, dan lain-lain. Apa yang diperjuangkan Irman Gusman melalui lembaga tinggi Negara yang dipimpinnya (DPD) juga memiliki kesamaan meski dibedakan oleh skala perubahan yang dituntut.

Ketika berada di Jakarta (Agustus 2016), saya menghubungi SBP untuk mendapatkan buku terbarunya yang terbit tahun 2014. Karena kesibukan dalam urusan waktu itu, saya tidak dapat bertemu SBP. Rekan saya asal Medan, Selwa Kumar, yang waktu itu juga berada di Jakarta dan tak memiliki urusan yang banyak, bersedia menggantikan saya bertemu SBP. Atas jasa Selwa Kumarlah kemudian SBP mengirimkan satu eksemplar buku itu kepada saya dua hari setelah permintaan saya diterima SBP.

Buku "Ganti Rezim Ganti Sistim, Pergulatan Menguasai Nusantara" adalah satu dari buku-buku yang ditulis SBP. Judulnya mudah mengundang salah faham. Buku SBP yang lain di antaranya "Pokok-pokok Pikiran Tentang Ekonomi Industri \& Pembangunan" (1996), "Sri-Bintang Pamungkas dan Daulat Rakyat" (1997), “Konstitusi Kita” (1999), “Menggugat Dakwaan Subversif” (200), "Dari Orde Baru ke Indonesia Baru Lewat Reformasi Total" (2001), "Membongkar Kebohongan Politik SBY-JK" (2006), "Menantang Seorang Diktator, Perjalanan di Jerman" (2008), "Politik Kenegaraan, Perekonomian dan Industri Kumpulan Tulisan 1993-1995" (2011), dan “Melawan Kediktatoran, Pergulatan Tak Kunjung Usai” (2014). Tulisan ini akan berusaha menceritakan secara ringkas isi buku edisi kedua "Ganti Rezim Ganti Sistim, Pergulatan Menguasai Nusantara”. Buku ini terdiri dari 4 bab pembahasan dengan 735 halaman di luar daftar isi dan kata pengantar.

Dengan gaya sangat khas SBP menuturkan perjalanan sejarah, ekonomi dan politik Indonesia mulai era Soeharto. Mengapa tak dimulai era Soekarno? Kelihatan SBP memastikan bahwa kerusakan Indonesia yang sangat serius justru terjadi sejak Orde Baru, meski pun sebetulnya jika akan berbicara kritis tentang penyimpanganpenyimpangan Indonesia dari jatidirinya sendiri sesuai Pancasila dan UUD 1945 yang 
dirumuskan oleh para the founding father, tingkah-tingkah Soekarno pun sebetulnya tidak dapat dipandang sederhana. Andilnya cukup luar biasa "merusak" Indonesia justru pada tahun-tahun pertama sebagai Negara merdeka. Saya malah memastikan penyimpangan dan kerusakan Indonesia itu terjadi setiap era kepemimpinan. Karena itu andil setiap pemimpin puncak Indonesia tidak sepi dalam peta kerusakan atau penyimpangan Indonesia itu. Karena itu pulalah setiap rezim yang saling menggantikan itu secara subjektif pasti selalu punya banyak bahan untuk "mencacimaki" rezim yang digantikannya sambil menjanjikan sesuatu yang secara subjektif dikampanyekan sebagai idealitas keindonesiaan sesuai cita-cita kemerdekaan. Jika sedikit mau agak sarkastik dalam pengungkapan, setiap rezim pengganti pasti memiliki bahan yang cukup dan sejumlah alasan tindakan yang dapat dibuat amat legitimatif untuk memenjarakan pemimpin yang digantikannya.

Dengan latar belakang kecurigaannya yang demikian besar terhadap pribadi kuat Soeharto dalam transisi Orde Lama ke Orde Baru, SBP menjelaskan peran kesejarahan Soeharto dalam menata perekonomian dengan hasil utama lahirnya para naga. Orde Baru bukanlah sesuatu yang mudah diluncurkan. Pertikaian pemikiran ideologis terjadi sangat dahsyat. Penyederhanaan Partai menjadi PPP, Golkar dan PDI bukanlah satusatunya kontroversi yang berdampak besar. Koreksi demi koreksi juga terjadi dan semua itu dapat dipatahkan.

Orde Baru memiliki senjata ampuh mengintegrasikan diri dengan kapitalis dunia khususnya melalui saluran Negara adidaya terutama dengan peran penting Mafia Berkley. Tetapi sucses story Soeharto tiga dasawarsa lebih berkuasa dapat tergusur oleh arus besar reformasi yang dilanjutkan oleh BJ Habibie adalah fakta bahwa Indonesia tidak pernah berdiri di atas kaki sendiri melainkan di atas rancangan para pihak yang memiliki kepentingan yang seakan jauh lebih besar terhadap Indonesia dibanding orang Indonesia sendiri yang selalu terlambat menyadari.

Sebagaimana diketahui BJ Habibie begitu rapuh dalam akar budaya politik Indonesia dan dia mengakhiri peran kepemimpinan nasionalnya begitu singkat meski dengan catatan penting memasuki demokratisasi. BJ Habibie itu dimangsa oleh para naga dan harapannya untuk menjadi presiden definitif pasca transisi, kandas. Rezim saling sikut Gus Dur-Mega yang berbagi 5 tahun periode kepemimpinan secara bergiliran adalah kejatuhan Garuda dalam belitan Naga, menurut SBP. Memang ada saja cara untuk menjatuhkan, tak hanya faktor keanehan-keanehan perangai khas Gus Dur. Swastanisasi yang berakhir penjualan aset-aset Negara sebagai salah satu fenomena penting menandai kepemimpinan Mega, bagi SBP adalah cerminan karakter nasionalisme ala puteri proklamator ini.

Era SBY selama dua periode kepemimpinan adalah pesta para naga sembari menjual ibu pertiwi. Kasus-kasus seperti bank century yang hingga sekarang didiamkan menjadi bukti besar bagi SBP menuding rezim ini, selain catatan tentang kasus Munir yang tentu tak terlupakan, Akhir periode kedua kepemimpinan SBY diwarnai kegamangan baru degan munculnya scenario para naga. Kandas dimanakah reformasi yang dicetuskan tahun 1998? Gus Dur lebih banyak berjalan ke luar negeri, Mega yang sangat kurang faham (dan salah satu bukti kuat kekurang-fahamannya itu ialah bahwa dalam keadaan berkuasa dan memiliki sumberdaya besar justru kalah dalam pilpres 
dibikin anak-buahnya sendiri yang membangkang dan tadinya amat disepelekan), lebih banyak hanya ingin menikmati kekuasaan yang selama beberapa lama didambakannya sebagai titisan darah Bung Karno. Maka stabilitas dalam pemerintahan selama dua periode di bawah kepemimpinan SBY-lah yang paling bertanggungjawab atas kegagalan reformasi.

Dalam kesimpulan SBP ada tiga gurita besar yang sangat berbahaya dalam ekonomi dan politik Indonesia, yakni penjajahan oleh bangsa sendiri, pengaruh atau dikte asing dan Eci (Etnis Cina Indonesia). Di bawah ketiga gurita berbahaya ini kerentanan Indonesia selalu terlihat dalam kisah kejatuhan Soekarno dan Soeharto, bagaimana korporatisme menunjukkan pekerjaan utama seolah menjual Indonesia Inc, membabat hutan tropis, menggadai migas, kronik Pertamina dan para mafia migas. Dahsyatnya peran ECI difahami oleh SBP dalam perspektif bahaya Tartar dan Politik, yang kini semua sudah semakin terbuka dan menjadi perbincangan serius di warkopwarkop anak muda. Terlambat disadari bahwa semua bersumber dari rangkaian amandemen terhadap UUD 1945. Karena itu SBP maju dengan konsepsi mengganti rezim penjajah untuk segera kembali ke cita-cita proklamasi. Penyuaraan tentang tuntutan itu sudah dilakukan sejak awal reformasi yang ternyata memang tak berhasil merubah lebih baik Indonesia.

Apa pandangannya tentang rezim pasca SBY? la bukan tak menyadari betapa sulitnya menyelesaikan dilema pemilu 2014 dan betapa berbahayanya Chinese Connection. la pun sadar politik "Dagang Sapi” yang tak terhindari dan sejumlah kejahatan terhadap Negara yang sangat tak terkendali. Dari pemilu ke pemilu yang membawa SBY menjadi Presiden selama dua periode bagi SBP tak lain dari kelanjutan dari intervensi asing belaka dalam mendisain Indonesia yang sebelumnha diawali dengan masuknya bantuan-bantuan asing dalam perkuatan demokrasi dan pemilu melalui sejumlah ornop, akhir tahun 1990-an.

Berdasarkan ramalan Joyoboyo (1135-1157) tentang para pemimpin Nusantara (hlm $v$ - xviii), SBP menyebutkan karakter yang melekat pada pemimpin-pemimpin Indonesia sejak era kemerdekaan. Mitos ini memang bukan sesuatu yang bersifat ilmiah, namun dalam tradisi budaya politik di Indonesia dengan aspek Kejawen yang kental, hal serupa itu dianggap sebagai hukum pinasti tak tertulis dalam "akal sehat". Soekarno adalah Satrio kinunjoro murbo waseso, orang yang semasa mudanya masuk penjara berkali-kali, pemimpin yang berjuang untuk memerdekakan Indonesia. Soeharto sang Satrio mukti wibowo kesampar yang berwibawa, berkuasa lama, tetapi meski kaya jatuh juga karena ulahnya sendiri. BJ habibie seorang Satrio jinumput sumelo atur gewe wirang. Sesungguhnya ia diangkat (lemah legitimasi), dan pengangkatannya itu seakan menyela (soeharto). Pekerjaan dipersepsikan membawa bala bagi indonesia dengan antara lain lepasnya Timor Timur. Gus Dur adalah Satrio lelono topo ngrame wuto ngiteri jagad. Sebagai kiyahi dianggap mestinya banyak berdiam, namun paling banyak ke luar negeri. Megawati Satrio piningit hamung tuwuh, nafsu kekuasaan tetap tumbuh dengan tiada henti-henti. SBY Satrio pinilih hamboyong pambukaning gapuro gelar klasa tanpa anglenggahi. Tak mampu membawa bangsa melintasi gerbang kemerdekaan dan segala kebijakannya seakan tak bermanfaat bagi rakyat. Siapakah pengganti SBY yang berkuasa selama dua periode 
melalui pilihan langsung itu? Dialah Satrio pinandio sinisihan wahyu ratu tanpa makuto yang melanjutkan pasca pemerintahan SBY.

Mitos itu tak menjanjikan harapan perbaikan. Karena itu ganti sistim bagi SBP adalah cara memutus tiga gurita besar (penjajahan oleh bangsa sendiri, pengaruh besar asing dan kemaharajaan $\mathrm{ECl}$ ) yang dirumuskan dalam 7 pilar dengan prasyarat kembali dulu ke UUD 1945 sebagai keniscayaan. Ketujuh pilar itu ialah (1) pilpres dirancang untuk terlaksana secara langsung (2) otonomi yang luas di tingkat provinsi (3) MPR sebagai lembaga tertinggi Negara merupakan gabungan DPR dan Dewan Perutusan Provinsi (4) penghapusan Dwifungsi ABRI (5) kemandirian kekuasaan Kehakiman yang tak dapat dikendalikan dengan cara apa pun dan oleh siapa pun (6) HAM dimasukkan dalam konstitusi (7) kesejahteraan rakyat dan keadilan sosial bagi seluruh rakyat sebagai tujuan bernegara dipertegas dan diperluas dalam konstitusi. Ini semua memang revolusi besar, tetapi tak mungkin terlaksana di bawah arahan seorang tokoh sipil tanpa harus melalui jalur tunggal, itulah langkah konstitusional. Bukan yang lain, seperti makar, misalnya.

Seserius apa tuduhan makar terhadap SBP sebagaimana diberitakan belakangan ini? Kita tunggu saja pihak Kepolisian melakukan tugasnya. Tetapi ada sebuah kisah yang mirip, yang pernah menimpa SBP dan sejumlah tokoh nasional ("Makar Ala Habibie", hlm 163-171). Intinya rezim ketakutan diperparah oleh lemahnya kemampuan intelijen menerjemahkan informasi yang bertaut dengan luar biasanya dikte-dikte para pelanjut penjajahan atas bangsa sendiri, kekuatan asing dan $\mathrm{ECl}$.

Kivlan Zen memang ada dalam daftar tuduhan makar itu. Tetapi meski mantan serdadu, ia dan SBP, Ratna Sarumpaet, Ahmad Dhani, Rachmawati Soekarnoputri dan lain-lain, tidak memiliki legitimasi apa pun memegang tongkat komando dengan pasukan yang siap dimobilisasi bagi perebutan kekuasaan. Karena itu kini Kepolisian sedang berusaha membuktikan makar tanpa pasukan. Sebuah penyimpangan dalam sejarah, politik dan kekuasaan yang kini sedang ditonton dunia. Para ilmuan sosial dari kampus pun rasanya tak mungkin tak tertarik menelaah keganjilan ini.

Shohibul Anshor Siregar Naskah ini pertamakali diterbitkan oleh Harian Waspada, Medan, 14 Desember 2016, hlmn B6 